How to cite this work: Guan, H., \& Cao, H. (2020). Gentrification in the Global South: new insights from Chinese Studies. Boletín de la Asociación de Geógrafos Españoles, (87). https://doi.org/10.21138/bage.3055

\title{
Gentrification in the Global South: new insights from Chinese Studies
}

\author{
Gentrificación en el Sur Global: \\ nuevos conocimientos de los estudios chinos
}

Haotian Guan

hguan@uottawa.ca

Huhua Cao

caohuhua@uottawa.ca

Department of Geography, Environment and Geomatics

University of Ottawa (Canada)

\begin{abstract}
Following the introduction of the "gentrification" concept by Ruth Glass in 1964, Anglo-Saxon urban geographers have extensively studied the process and phenomenon of gentrification. In recent years, gentrification studies have moved beyond the Anglo-Saxon academic field. This paper aims to review the current stage of English-Language gentrification studies about China. Using the case of China, the paper argues that gentrification can be generalized to a universally applied paradigm. However, the challenges of studying gentrification in any country are to transfer and adapt the broad paradigm that could capture the complexities of local conditions. Scholars studying gentrification in China have recognized the local and national differences that are specific to China and have worked out to establish their own theories.
\end{abstract}

Key words: state-led gentrification; gentrification in China; rent-gap theory, urban renewal; displacement. 


\section{Resumen}

Tras la introducción del concepto "gentrificación" por Ruth Glass en 1964, los geógrafos urbanos anglosajones han estudiado ampliamente el proceso y el fenómeno de gentrificación. En los últimos años, los estudios de gentrificación han movido más allá del ámbito académico anglosajón. Este documento tiene como objetivo revisar la etapa actual de los estudios de gentrificación en inglés de China. Utilizando el caso de China, el documento sostiene que la gentrificación puede generalizarse en un paradigma de aplicación universal. Sin embargo, los retos que plantea el estudio de la gentrificación en cualquier país consisten en transferir y adaptar el amplio paradigma que podría captar las complejidades de las condiciones locales. Los académicos que estudian la gentrificación en China han reconocido las diferencias locales y nacionales específicas de China, lo que les ha permitido establecer sus propias teorías.

Palabras clave: gentrificación dirigida por el Estado; gentrificación en China; teoría de la brecha de renta, renovación urbana; desplazamiento.

\section{Introduction}

The term "gentrification" was introduced by Ruth Glass in 1964. Glass described and examined the phenomenon of replacing the working-class population with the middle class groups in the inner urban neighbourhoods of central London in the 1950s and 1960s. Following the introduction of the "gentrification" concept, Anglo-Saxon urban geographers have extensively studied the gentrification phenomenon. The classical theory distinguishes gentrification from redevelopment. Redevelopment is defined as the "construction of new buildings on previously developed lands," whereas gentrification is "the rehabilitation of old structures" (Smith, 1982, p. 139). By the 1990s and 2000s, the classical narrow view of gentrification came to a stagnation. What was previously perceived as "redevelopment" came to integrate into the gentrification concepts, and gentrification has started to be referred to as a broader concept of neighbourhood change. Davidson and Lees (2005) provide one of the most influential works to broader the concept of gentrification. By looking at the redevelopment of central London along the River Thames that mostly associated with new-builds at brownfield sites rather than redevelopment of old dwellings, Davidson and Lees (2005) redefine gentrification components as "(1) reinvestment of capital; (2) social upgrading of locale by incoming high-income groups; (3) landscape change; and (4) direct or indirect displacement of low-income groups" (p. 1170). These four components are heavily used in later gentrification research. 
Early gentrification studies recognized the private actors as the driving force behind gentrification. State and policy were mostly considered as an aid to the processes (Smith, 1979). Smith (1979) provided one of the most influential production-based explanation of gentrification based on rent-gap theory, highlighting recognizable differences between current rental incomes and potential "best use" values and the likelihood of redevelopment as investors identify profitability opportunities. To some researchers, the role of policy and state in gentrification has become more prominent, especially in the case of studying "new-build gentrification." Driven by the neo-liberal urban policies of top-down planning processes and public-private partnerships, states see gentrification as the solution to regenerating low-income neighbourhoods and play a more aggressive role in the gentrification process (Cameron, 2003).

Counterpoised to the production-side based theory, Ley (1986) observes the consumption-side of the explanation and argues that gentrification began with changes to societal needs. The demand for gentrification is coming from the "new middle class" created under the post-modern economy, composites of "relatively affluent, young, child-free couples' in professional, managerial and advanced service occupations" (Ley, 1994; Palen \& London, 1984; Shaw, 2008, p. 1718), who rejects the mass-produced suburban in favour of "a reclaimed boutique life of creativity, tolerance, and social mixing in funky, lived-in urban centres (Jackson, 2017, p. 52)." The "new middle class" chooses to move back to the inner city to discover the demographic and cultural diversity. They enjoy the gentrified old houses, heritages, and factories that got converted to residential dwellings. Through the process of gentrification, low-income households, mostly longer-term, often working-class populations who traditionally live in the urban core, get displaced. Gentrification, indeed, is "the class remake of the central urban landscape (Smith, 1996, p. 39)".

In recent years, the focus of gentrification debates has moved beyond consumption versus production side. Rather than analyzing the explanation from only one side, the research studies the gentrification process under an integrated theory. Clark (1988) argues that one should look at different theories with a complementary lens. Similarly, Hamnett (1991) suggests that an integrated theory of gentrification should be formulated, which not only focuses on production and consumption but also includes a more holistic and integrated explanation of "both the production of devalued areas and housing and the production of gentrifiers and their specific consumption and reproduction patterns" (p.173). Ley (2003) later recognizes that the research should not only analyze the production (economic) or consumption (cultural) side but rather note how the two sides work together to produce gentrification as an outcome. 
With the expansion of the gentrification theory beyond consumption and production, what is considered as gentrification has also expanded. For example, commercial aspects of neighbourhood updating gain popularity in gentrification studies. Commercial gentrification involves the transformation of local-run stores into upscale shopping, dining or even chain stores, which limited the local retail stores and services, that long-term, lower-class residents relied on, and drove out those who can no longer shop and eat in the neighbourhood they lived at, as well as driving the neighbourhood to higher rents which can only be afforded by the more affluent (Mermet, 2017; Zukin et al., 2009). Another example is environmental gentrification, which is about the significant increase in price in the communities with a notable improvement of environmental quality (Banzhaf \& Walsh, 2008; Sieg, Smith, Banzhaf \& Walsh, 2004). No matter the forms of gentrification, all the results look similar, hence putting the lower class population into an even more disadvantaged position.

More recently, gentrification studies have moved beyond the Anglo-Saxon academic world (Betancur, 2014; Janoschka, Sequera \& Salinas, 2014; Lees, 2016; Ley \& Teo, 2014; LópezMorales, 2015). Smith (2002b) argued that gentrification was no longer an urban strategy only in the traditional Global North countries, but has also become a globalized process that "densely connected into the circuits of global capital and cultural circulation" (p. 427). From a political economy perspective, gentrification is a way for capitalism to create new opportunities for accumulation. Harvey (2003, p. 144) coins the framework of "accumulation of dispossession," which describes how capitalism increasingly and persistently renewal and expand production by commodifying dispossession of the public interests with four features - privatization, financialization, management and manipulation of crisis, and state redistributions. Privatization and financialization were adopted as part of the neoliberal transformation from state welfare started in the 1970s. These two features enhance accumulation through the means of the urban built environments and privatization of public services (Aalbers \& Christophers, 2014; He, Zhang \& Wei, 2020; Zhang \& He, 2018). Public housing is getting reduced and disinvested, and private housing is dominated as the new housing format. This transformation brings competition between different socio-economic classes and provokes gentrification (He et al., 2020; Zhang \& $\mathrm{He}, 2018)$. Crisis manipulation and state redistribution are about the state to invest in a spatial fix to sustain capital accumulation and stimulate growth. It represents in the form of large-scale urban redevelopment as a macroeconomic tool to solve internal economic setbacks (He \& Wu, 2009; He et al., 2020; Zhang \& He, 2018). These two features are not very common in Western countries. However, they are often associated with developing countries. The central government 
pushed public housing provision, housing privatization, and large-scale urban redevelopment to solve economic issues. Many times, these changes are associated with large scale state-led gentrification (Zhang \& He, 2018).

Seeing as a way of capitalism to increase accumulation and a strategy under neoliberal urbanism, the global reach of gentrification gained a lot of popularity worldwide, and the studies of globalized gentrification processes in cities in developing countries emerged. Smith (2002b, p. 196) sees gentrification as a global urban strategy and argues that "gentrification is happening on a more massive scale in Shanghai or Mumbai ... than in the older post-industrializing cities of Europe, North America and Oceania". Betancur (2014) reviews gentrification studies of Latin American cities and sees three elements stand out in the Latin American's gentrification. First, gentrification is imported from the Global North through a consortium of international agencies with local governments in the form of public-private, international-national cooperation. Second, Latin American's economies' hybridity makes the markets respond differently to the forces that promote gentrification. Finally, the traditional format of gentrification is less appealing to the Latin American since gentrification in Latin America is more relying on the new constructions of highrises in exclusive locations rather than on the rehabilitation and redevelopment of traditional central areas. Visser and Kotze (2008) observe the new-build and office conversion types of gentrification are the driver of the redevelopment of inner-city in Cape Town, South Africa, and argue the "new" gentrification is the central part of urban regeneration. Ghertner (2015) looks at gentrification in Mumbai, Rio, and Luanda, and argues that the violence displacement in postsocialist and post-colonial cities associated with land transformation and privatization is often ignored in gentrification studies.

At the same time of growing gentrification studies in Global South cities, the conceptual adaptation of gentrification outside Anglo-Saxon societies was also challenged. For example, Atkinson (2008) expresses concerns about the generalization of neighbourhood change to gentrification as "this elasticity has reduced the bite of critical studies of its localized appearance and has diminished policy-maker interest as a result" (p. 2634). Maloutas (2012) argues that gentrification in Anglo-Saxon cores has its own contextual origins, whereas the transformation of gentrification outside of Anglo-Saxon societies sometimes adopts the same processes without considering the complexities of local conditions. The study of gentrification in China has recognized these challenges and has established its own theories. 
In China, the first study of gentrification was introduced by Xue (1999), who reviewed the theory, origin and process of gentrification in Anglo-Saxon studies and made the connection toward urban renewal. Since then, gentrification studies have started to gain popularity. At that time, Xue (1999) challenged the transferability of the concept of gentrification from Anglo-Saxon studies to China since he believed that gentrification follows a process from urbanization to suburbanization and then toward gentrification. In contrast, China has not experienced the transformation from urbanization to suburbanization yet, and the driving force comes mainly from the government rather than the private actors. Meanwhile, Xue (1999) recognized the appearance of socioeconomic segmentation in China, which is a factor that potentially leads to gentrification. Since the study of Xue (1999), gentrification research has gained popularity in Chinese academia and gentrification theories are being developed with Chinese characteristics.

Using the case of gentrification in China, this paper argues that the study of gentrification could use a universally applied paradigm, which in terms of the concept, gentrification can be generalized as about neighbourhood changes and its related social-economic changes. In terms of the theories, gentrification can be captured through production-based and/or consumptionbased theories. In terms of the consequences, gentrification is all resulting displacement of residents. However, the challenges of studying gentrification in any country are to transfer and adapt the broad paradigm to capture the complexities of local conditions. Scholars studying gentrification in China has recognized the local and national differences that are specific in China and has worked out to establish its own theories. Gentrification is a Anglo-Saxon theory and concept that, when applying in China, it would require considering China's unique historical socialist background, especially some of the socialist legacies that are still influencing China today. For example, the inherited urban and social forms established under Mao's socialist China, the continued existence of strong state control, and the increase of societal demands from the people have all driven gentrification in China. At the same time, these features are making China's gentrification theories and concepts different. More recently, we see some new trends of gentrification in China that have become increasingly similar to what has been observed in AngloSaxon countries.

The following section of this paper introduces the methodology used in the study, follows by discussing the progress of Chinese gentrification studies with the focus on the adoption of the Anglo-Saxon gentrification concepts and theories in a Chinese concept. Afterwards, the paper discusses the gentrification-induced displacements that particular to China. The last part of the 
paper covers the future of gentrification studies in China, and the significances of the Chinese gentrification research in contributing to global gentrification studies.

\section{Methodology}

This study is based on a review of existing English-language academic studies concerning gentrification in China. The initial search of the peer-reviewed articles aimed to identify articles published through September 30, 2020, using Clarivate Analytics' Web of Science citation database. The authors went through all studies in the database that have both "gentrification" and "China" in their titles, abstracts or author keywords. Only English language articles related to Mainland China were selected in the study. The initial search provided an inventory of 128 articles meeting the criteria.

The authors used Statistical Analysis Toolkit for Informetrics 4.0 (SATI) to conduct a bibliometric analysis and to reveal some of the general trends of English-Language based Chinese gentrification studies. The analysis on time distribution of the 128 publications showed Chinese gentrification studies emerged in 1997, gained awareness between 2007 and 2015, and received significant popularity since 2016 (Figure 1).

Figure 1. Time distribution of English-language gentrification studies about China

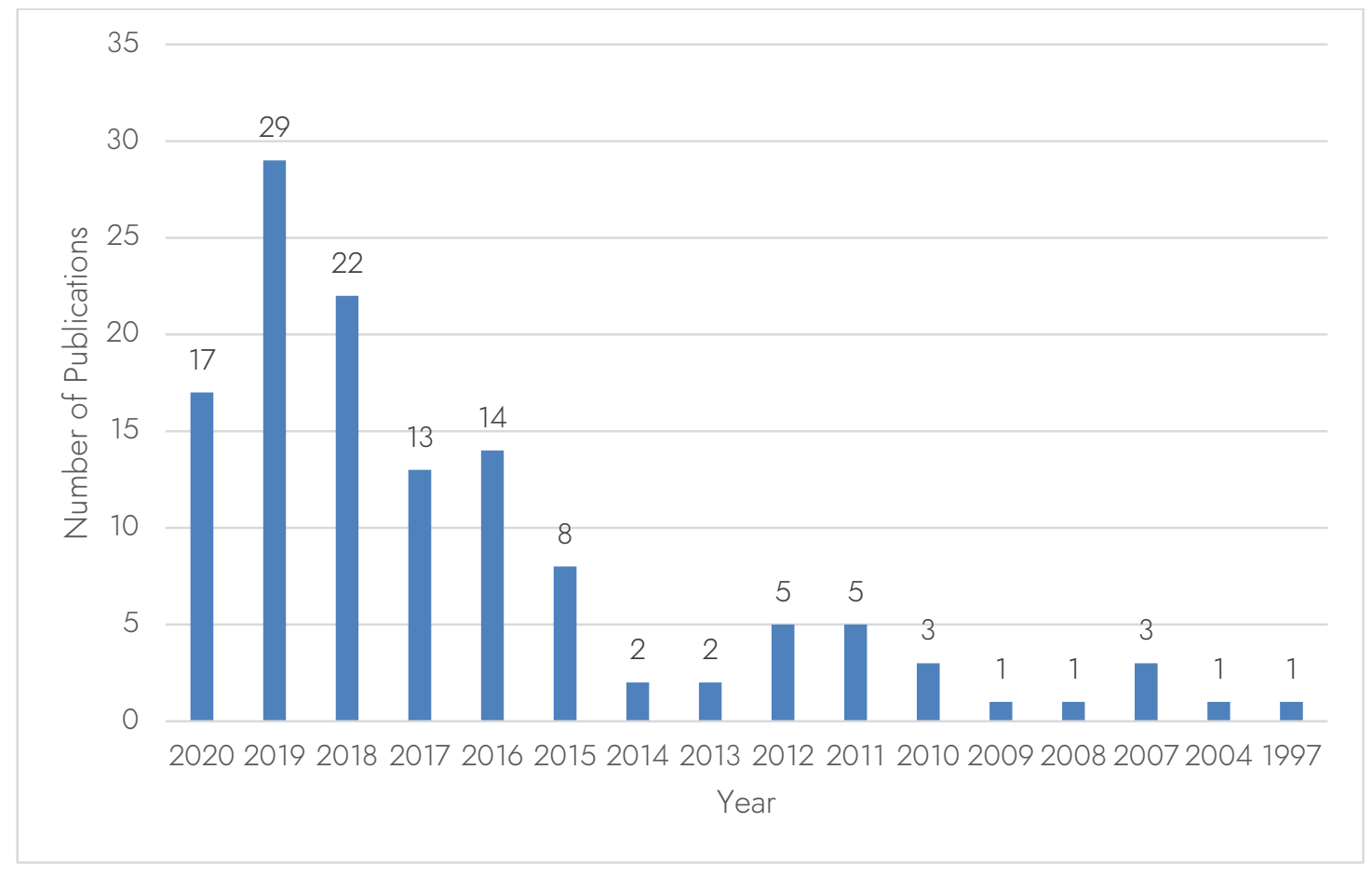

Source: authors' elaboration based on SATI analysis 
The keyword analysis showed the Chinese gentrification studies had a geographical concentration on Shanghai (14 articles) and Beijing (11 articles). There were less focuses on other $1^{\text {st }}$ and $2^{\text {nd }}$ tier cities, like Nanjing (6 articles), Guangzhou (5 articles), Shenzhen (3 articles), and Chengdu (2 articles). ${ }^{1}$ The analysis also revealed the Chinese gentrification studies had a focus to explore concepts and theories. These studies had significant connections with urban redevelopment (13 articles), urban regeneration (6 articles), and urban renewal (5 articles). Newer gentrification concepts, like jiaoyu-fication (education-led gentrification) (3 articles), rural gentrification (3 articles), commercial gentrification (2 articles), and tourism gentrification (2 articles) started to emerge in Chinese studies. These concepts got explained by different theories like cultural capital (3 articles), commodification (2 articles), market transitions (2 articles), and neoliberal urbanism (2 articles). The analysis also revealed the current studies try to explore the consequences of gentrification - mainly displacement (7 articles). Figure 2 shows the focuses and connections of different concepts, theories and consequences of gentrification based on the keyword analysis.

To increase the comprehensiveness of this study, the authors examined the bibliographies of all the 128 articles and added some of the most frequently referenced articles that were excluded from the Web of Science database in this study. The authors also added books and book chapters written by authors who made significant contributions in the field of gentrification studies to this study. In addition, the authors used some articles, books, reports, and news regarding China's urbanization to provide background information in order to better explain gentrification in China. The main limitation of the methodology is it largely ignores the studies that describe gentrification-like processes unless the word "gentrification" appears in the titles, abstracts or author keywords of articles. As discussed in the following sections, gentrification in China is often associated with state-driven urban renewal and restructuring processes. Scholars may not explicitly use the term "gentrification" to describe these phenomena.

1 There are different divisions and interpretations of the tiered city system in China, with minor differences. A common perception of the 1st tier cities are Beijing, Shanghai, Guangzhou, and Shenzhen. A detailed explanation of the tied city system in China can be found at https://multimedia.scmp.com/2016/cities/. Based on the South China Morning Post, who obtained the information from China Statistical Yearbook 2013, there are 613 cities in China, which are divided into four tiers based on taking into consideration of GDP, politics, and populations. The 1st tier cities include 5 cities, the 2nd tier cities include 30 cities, the 3 rd tier cities include 137 cities, and the 4th tier cities include 441 cities. Another well-accepted interpretation is published by the China Business Network - the Most Commercially Charming Cities in China. 
Figure 2. Knowledge graph based on the keyword analysis

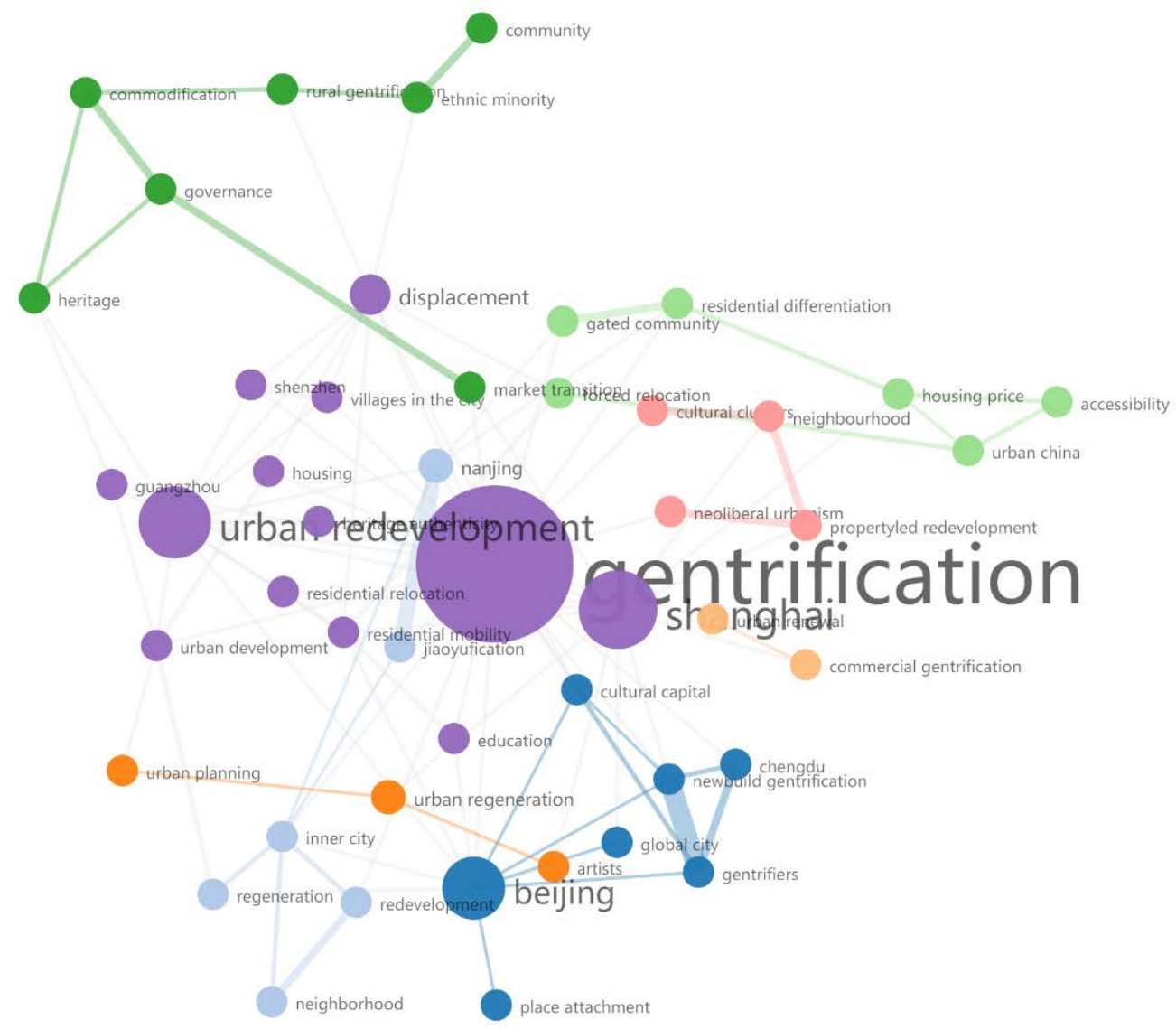

Source: authors' elaboration based on SATI analysis

\section{Chinese concepts of gentrification}

Although gentrification is a relatively new concept introduced to Chinese scholars by Xue (1999), the conceptual understanding of gentrification has grown rapidly in recent years. The broad concept of gentrification is about the change of neighbourhoods and its associated socialeconomic classes. Gentrification is about neighbourhood change but is also beyond neighbourhood change in China. Traditionally, gentrification in China is considered a state-driven urban renewal and restructuring process that takes account of the socialist legacies. The process is intended to create and to result class transformation and transformation of housing. The scope of gentrification in China is way beyond the concept of state-led gentrification that is captured in the Anglo-Saxon studies. Gentrification in China is a process that parallels to other urbanization processes, like urban expansion and suburbanization in China. Under Mao Zedong's socialist China between 1949 to the late 1970s, the country's economy is centrally planned with focuses on industrialization. Mao's vision of the urban is to create a socialist city of production by the 
working class. Urbanization was held back in order to avoid the "embarrassment of a large number of educated but unemployed youth [in the city] (Friedmann, 2007, p. 267)". The urban worker population was stabilized at around $17 \%$ of the total population, and they were considered as the privileged class, and they enjoyed free housing, education, food subsidies, and free health care (Friedmann, 2007). Under this vision, state-run danwei (production unit) was the most crucial element of socialist urban spatial structure. ${ }^{2}$ The gated danwei contained people's work and life in the urban. Danwei functioned not only for production but also provided residence and social welfare (Chai, 2014). In 1978, nearly 95\% of the urban workforces were employed by danwei and lived in danwei's resident compounds (Chai, 2014). Under this statecontrolled socialist system, there was no official real estate market in China. The goal of creating a city for only the working class based on work units, with free housing for workers based on central allocation, created problems like housing shortages, massive government financial burden, and urban zoning issues (Wang \& Murie, 1996).

The economic reform started in the 1980s, promoted a socialist market economy. The socialist workers were no longer the driving force behind economic growth. Cities are not only for the socialist workers anymore. The traditional state-run danwei declined along with the growth of private industries. Urbanization came to the table for the Chinese state's agenda. Urban construction and manufacturing industries have attracted a massive amount of the rural population to migrate to the cities to work. The growth of the middle-class population in the cities has become the new driver of economic growth. Cities in China experienced an urban restructuring based on class and demographic shifts.

However, the urban structures that built based on an ideal socialist worker's city remain. The issues of run-down public housing and housing shortages that were created in the socialist era needed to be solved. The land and property reforms recognized the demand for better housing. The middle class created after the market reform could, for the first time, purchase houses based on their preferences. Under this context, $\mathrm{He}$ (2010) argues that gentrification is a class remaking process that displaced the low-income population to make room for the high-income middle-class residents in the urban. Meanwhile, the decentralization of governance to the city level put much

2 Under the era of China's controlled economy, danwei was a local organizational unit of workers that set production goals, slogans, and educational mottos, and controlled the spatial distribution of residents (Weiler, 2015, p. 22). Danwei has historically been the most important link between people and the state, providing employment, housing, comprehensive social services, and facilitating mass mobilization campaigns of the CCP (Gaudreau, 2013, p. 19). 
pressure on the local government, and the budgetary pressure was resolved through land commodification, which contributed to nearly $40 \%$ of funding for urban maintenance and construction (Lin, 2012; Ren, 2015).

With these historical backgrounds that specific to China, the first wave of gentrification took the form of large-scale redevelopment directed by the local government earlier in the 1980s to late 1990s, and then in the form of massive infrastructure investment, city beautification, and urban upgrade driving by neoliberal urbanism and now it shifted through shantytown redevelopment schemes under state-led financialization ( $\mathrm{He}, 2019)$. Each phase of gentrification in China was associated with urban renewal, but with different goals in mind. In each phase, the Chinese state played a comprehensive and prominent role in driving the state-led gentrification. He (2007) describes a stage model of state-led gentrification in China that started with the state to stimulate consumption demand through market reforms and policy initiatives. For example, the 1988 housing reform fostered the privatization of housing and allowed the previous state-distributed welfare housing to be sold to employees of public enterprises at a low price, and the 1998 housing reform ended the state distribution of welfare housing and set up new housing financing and market systems that allowed purchasing houses based on individual's preference (Man, Zheng \& Ren, 2011). The government then invested heavily in city beautification and infrastructure construction to attract developers to initiate gentrification in these desirable neighbourhoods and consumers to move into the newly gentrified neighbourhoods (He, 2007). Finally, the state would use its state power to tackle the problem of fragmented property rights and facilitate gentrification (He, 2007).

The traditional meaning of gentrification in China could not be separated from urban restructuring and urban renewal with the state as the driver. Unlike the Anglo-Saxon concepts on gentrification, which traditionally focused a lot on individual gentrifiers at the neighbourhood level, in China, most of the gentrification studies do not recognize the individual gentrifiers' concept of spontaneous and piecemeal housing rehabilitation because of the fragmented property rights in China (He, 2007). In China, most urban residents live in apartment complexes that consist of thousands of people. It is almost impossible to making rehabilitation or redevelopment of the apartment complexes through individual gentrifiers. It relies on a massive amount of planning through the local government to make it possible. However, the recent development on the concept of gentrification in China has expanded beyond to understand gentrification as a form of state-led urban restructure and urban renewal. More recent second wave studies start to capture gentrification in China that similar to the traditional Anglo-Saxon private-driven concepts. For 
example, there are two related but distinct forms of gentrification - studentification and jiaoyufication (education-led gentrification), are emerging in China's gentrification studies.

Studentification is a term coined by British geographer Darren Smith in 2002 to capture students in stimulating changes and driving restructuring in neighbourhoods (Smith, 2002a, 2004). He (2015) captures a similar phenomenon of studentification in China. He (2015) sees some tremendous transformation of the economic, physical, social, and cultural landscapes close to universities. The author argues that studentification in China as "the result of students conscious residential, entrepreneurial and consumption choices to escape from the rigid control of university dorms, to accumulate cultural and economic capitals, as well as to actualize their cultural identity (He, 2015, p. 2849)." On the other hand, jiaoyu-fication (education-led gentrification) captures a phenomenon of well-off middle-class parents to place their children near leading public schools in cities in China. Wu, Zhang, and Waley (2016) observe parents purchase apartments in the catchment zone of leading public schools at an inflated price, and the sellers are guaranteed a good price without any rehabilitation, and it results in a displacement of the original residents.

Gentrification, in the form of rehabilitation in China, is most common in heritage sites. For example, Arkaraprasertkul (2018) studies the gentrification of lilong (lane houses) in Shanghai, which was built by the foreign settlement between the late-19 ${ }^{\text {th }}$ century and the mid-1940s. The local residents in lilong, mostly working-class residents - traditional socialist workers and later migrants, see the historical significance in these dwellings, sell the lilong as historical heritage preferred by the middle-class, and profit from the transaction. Rather than the middle classes pushing out the working-class, which puts the working classes in a disadvantaged situation, the case of lilong recognizes the profit the working class can obtain from the rehabilitation process.

The gentrification of heritage sites also closely connects to the concept of tourism gentrification. For example, González Martínez (2016) studies the rehabilitation of siheyuan (courtyard houses with four walls) into commercial sites like stores and restaurants for tourists. However, the study is limited to the scope of looking at urban authenticity in relation to producing higher value. Chan, lankova, Zhang, McDonald, and Qi (2016) study the Honghe Hani Rice Terraces World Heritage and observe the transformation of the indigenous dwellings into guesthouses or restaurants by the local indigenous entrepreneurs. Chan et al. (2016) define the transformation as "selfgentrification" as follows: 
Under the threat of other forms of gentrification, the long-term residents adopt a proactive approach to become the 'gentry' themselves. As such they are able to benefit from the positive aspects of gentrification whilst avoiding many of the negative effects, particularly displacement (p. 1265).

Through self-gentrification, the original residents would benefit from the process as they would be able to obtain most of the value, particularly in a monetary form.

More recently, a newly emerged long-term rental format has significantly impacted rental tenants in China but has not been studied under the concept of gentrification yet. Based on a new business model of branded property management with dispersed properties through a "light

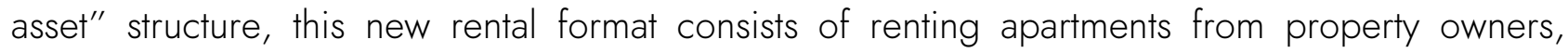
renovating based on standardized template styles, and then leasing such properties for premium prices while providing additional add-on services. With these processes, tenants are prepared to pay premiums of $30 \%$ to $60 \%$ more for branded apartments than the rate of barebones units (EHouse China, 2018). This trend is transforming the long-term rental market in China. There are approximately 1.5 million dispersed units throughout $1^{\text {st }}$ tier cities in China, amounting to $74.56 \%$ of total long-term rental apartments (E-House China, 2018). In the absence of re-development of entire blocks or apartment buildings, questions arise about whether this is gentrification on a micro-scale considering the small unit size and extensive quantity. This means $9.4 \%$ of all rental units in Beijing have undergone gentrification with the potential for profound effects on the rental market and individual livelihood. The aggressive expansion of dispersed branded long-term rental reduced the number of traditional units in the markets (Xinhua News Agency, 2018). In addition, this new format of rental in China is closely related to "fifth wave gentrification" studies in AngloSaxon studies, which backed by platform capitalism (i.e. real estate platform - Ziroom, Uoko, Danke) and corporate capitals (i.e. real estate investment trust and real estate private equity) (Aalbers, 2019). The significance of the new business model is worth examination in future gentrification research in China.

The broad concept of gentrification is about the change of the neighbourhood and its associated social-economic classes. This concept is used in both Anglo-Saxon and Chinese studies. However, the differences in the urban development path made the details of the concepts different. Gentrification in the Anglo-Saxon theories traditionally captures class transformation in the inner cities by rehabilitating residential dwellings individually at the neighbourhood scale. Then the role of policy and state becomes more prominent under neoliberal urbanism. The inner 
urban renewal strategy led by the state in many developed Western countries is now through gentrification. On the other hand, gentrification in China is a strategy that is embedded in urban restructure and urban renewal to deal with the urban socialist legacy issues initially, but gentrification increasingly becomes an urban growth strategy. It is used to create but also to result in class transformation and transformation of housing. Gentrification is a process bounded within urban renewal, but it is not a driver of urban renewal. More recently, the study of gentrification has expanded beyond state-driven urban renewal to studying a more diverse format of gentrification that is similar to the traditional Anglo-Saxon concept of gentrification.

\section{Chinese theories of gentrification}

Chinese scholars build their gentrification theory based on the production and consumption sides of explanations with the recognition of the socialist legacies in mind, specific on the strong state presents in producing gentrification, and also the change of people's societal needs after moving away from the Mao's socialist to the market economy. Chinese scholars recognize the rent-gap theory in explaining gentrification. However, rather than a rent gap driven by the market, Chinese scholars recognize the differences in Chinese land systems, which results in the state worked as an agent in determining the rent gap. Song, Liu, Wang and Yuan (2017) integrate the rent jump theory on top of the traditional rent gap theory of gentrification.

The rent jump theory adds the complexity of the land ownership system in China to the explanation. Before the land reform in the 1980s, China had a public housing system whose useright was assigned to individuals by the states. The housing reform created a complex and fragmented structure of property rights system in which the state is the owner of the land, and the individuals only have the land use rights (He, 2007; Wang \& Lau, 2009; Wu, 2016). The land and market reform create an entrepreneurial local government that allows for selling the land use rights to individuals/developers and obtaining revenue from land sales. As the local government holds land ownership, the government profits from the withdrawal of use-rights from individuals by providing monetary compensation to the users based on the minimum government standard rather than the current rent income. Then, the government sells the use-rights to developers that are close to the "best use" value. This rent jump outside of the market-orientated rent gap becomes one of the most significant revenue resources to the local government (Song et al., 2017; Song \& Wu, 2010; Song \& Zhu, 2011). Wu (2016) expands the rent jump theory by studying the "ownership swap" strategies used by the local government, which involves the resettlement of the displaced community to different locations as a form of compensation. As the 
land use and construction prices in the resettlement locations are generally low, ownership swap creates more revenue for the local government than regular monetary compensation $(\mathrm{Wu}, 2016)$. The study of the production-side of gentrification in China expands on the rent gap theory and adds the political and social complexities that are specific to China into the theory.

Scholars working on gentrification in China also study the consumption side of the driving force, which is different from the traditional Anglo-American studies based on the change consumption preferences of the middle class. He (2007) draws the connection of the consumption-side of gentrification with the land and property reforms and the economic reforms that started in the 1980s, and recognizes the demand for better housing due to under-development and low housing quality during the Mao's Socialist era. The middle class created after the market reform could, for the first time, purchase houses based on their preferences rather than living in previously state-assigned houses (He, 2007). Song and Zhu (2011) reveal one of the significant differences between China and Western countries is that urban centres in China have always attracted people due to their service facilities and built environments. In Western countries, gentrification happens as part of the re-urbanization processes where the middle classes reoccupied working-class neighbourhoods in inner cities after the society already experienced urbanization and suburbanization; but in China, suburbanization is only a recent phenomenon (Song \& Zhu, 2011). Chinese scholars recognize that gentrification in China involves the process of moving the previously dispersed high social and economic status groups to regather in certain gentrified urban spaces, especially in the form of gated communities (Song \& Wu, 2010; Song \& Zhu, 2011). Wang and Lau (2009) further argue that group preferences rather than individual preferences behind the cultural-consumption aspect of gentrification, which the new professional middle-class sees moving into the gentrified neighbourhoods that were occupied by the upper class as a way to "buy-in" to the upper class by copying their lifestyle. These newly gentrified neighbourhoods have a symbolic value that expressed in the housing values. Wang and Lau (2009) predict that this social trend to copy the lifestyle of the upper classes would drive the expansion of gentrification in China. These studies on the consumption side of gentrification show that the gentrification studies in China do not simply copy and apply the Anglo-Saxon theories but consider the complexities of local conditions to create new theories.

In both Anglo-Saxon and Chinese theories, gentrification can be explained through a rent-gap theory or a theory of changing societal needs. However, the details under the theories are different. Considering the production-based theories of gentrification, when applying to Western countries, the rent gap theory is considered a logical economic behaviour of individuals seeking 
profits. More recently, this rent gap is captured by the state as a way for capitalism in crisis to create new opportunities for accumulation. In China, the rent jump theory is the modified version of the rent gap theory considering the strong state influence in the land market. It is unique to China's historical socialist background, especially the legacy of strong state control. The same applies to the consumption-based theories. Anglo-Saxon theories capture the change of societal needs from the "new middle class" who created from the transformation to the post-modern economy. These "new middle class" prefers the demographic and cultural diversities and the transformed boutique dwellings. Instead, Chinese theories also capture the change of societal needs that came from the middle class that created after the market economy transformation, who demand better housing and copy the higher-class lifestyle. Thus, although the broad theories of gentrification are the same, there are adaptions in the Chinese theories to cope with its particular background.

\section{Gentrification-induced displacement in China}

The most discussed consequence of gentrification is displacement. Displacement is about a process of eviction, expulsion, or exclusion of certain individuals, groups, or establishments in certain areas and on different scales. Displacement is a defining feature of gentrification dated back to when Ruth Glass first coined the term gentrification in 1964. She states, "altogether, there has been a great deal of displacement. All those who cannot hold their own-the small enterprises, the lower ranks of people, the odd men out - are being pushed away (Glass, 1964, pp. 25-26)." In China, displacement takes on a more massive scale due to widespread state-led gentrification in the form of urban renewal. Mostly, the state-led gentrification involves the total demolishing of the sites. Comparing gentrification-induced displacement in China to Western countries, on-site relocation is possible in many cases in China. Liu and Wang (2018) study Beijing's urban village redevelopment believe that the Beijing Municipality implemented gentrification in a "systematic and people orientated" manner and find that most of the redeveloped settlements are on-site in order to reduce inconveniences. Also, the affected landlords were offered a generous compensation package for swapping their resident plots. Many times, they would receive multiple apartments as well as rental subsidies. Liu and Wong (2018) show that in the Haidian District of Beijing, the compensation of resettlement allows landlords to swap their lands (100 to 400 square metres per household) for four to eight apartments, and each worth US\$300,000 - US\$760,000). Indeed, the resettlement created two phenomena in China, chaiqian baofahu (parvenu from resettlement) to describe those who 
received a fortune from the government's resettlement program, and chai'erdai (second generation parvenu from resettlement) to describe those young resettled residents to spend a fortune on luxury products, especially cars.

However, gentrification-induced displacement is not without issues. First, migrant workers' rights are not protected in the process. There is a lack of protection of tenancy rights. Migrants are always marginalized in Chinese cities even if they make a significant contribution to the cities' development (Shin, 2013). The hukou (household registration) system is still classifying migrants as temporary residences and treating them as noncitizens, resulting in migrants being excluded from resettlement compensation (Shin, 2013; Solinger, 1999). ${ }^{3}$ In Beijing, a recent wave of shantytown redevelopment was triggered by a deadly fire on December 18, 2017 that killed 19 migrant workers in an illegal rental apartment building in an outskirt shantytown in Beijing. The local government pushed out a clean-up campaign to evict the "low-end" population within 40 days, whereas in some locations, the migrant workers were forced to move out within a three-day notice (Kaiman, 2017; Phillips, 2017). Some media and government reports show the cleanout of migrant workers in shantytowns involved at least 135 areas in Beijing and impacted at least 100,000 people, mostly migrant tenants (Congressional - Executive Commission on China, 2018; Shi, 2017). These migrant workers are those being gentrified. The eviction of the "low-end population" connected with the "shantytown redevelopment project" aimed at replacing old neighbourhoods with new residential, business and public areas (Elmer, 2018). In addition, the upcoming 2022 Winter Olympics in Beijing would potentially create a new wave of shantytown redevelopment like the time before the 2008 Summer Beijing Olympics. The significant impacts on the migrants due to direct displacement caused by gentrification should be emphasized in future gentrification research in China.

Second, displacement from state-led gentrification has accompanied by continuous physical violent conflicts. It is especially the case for the forced eviction of the "nail households," who strongly oppose housing demolition and resettlement. Liu and $\mathrm{Xu}$ (2018) examine violent demolition incidents in recent years and discover the refusal from the government to meet "nail households" demands always lead to violent conflicts, even self-immolation, and unlawful killings.

3 Chinese House Registration System (Hukou) which was established in 1958, characterized dual citizenships: The Urban Hukou and Rural Hukou. The Urban and Rural Hukou differ on the basis of social welfare and accessibility to social-economic resources (Li, 2018, p. 2). An initial reform on the hukou system in 1984 eased the restrictions to allow rural population to work in cities, which paved the way for accelerated urbanization in China (Liu \& Cao, 2016). In 2004, a reform that aimed to unify the dual citizenship was initialized (Li, 2018). 
Third, mental and phenomenological violence is also significant in gentrification-led displacement in China. Zhang (2018) conducts studies on local residents who lost their homes to the World Expo 2010 in Shanghai and discovers domicide effects on those being displaced. According to Zhang (2018), the resident experiences mental and emotional violence due to "a partial elimination of their identities, destruction of their attachment structures and an assault on their dignity and decency (p. 208)."

Comparing Anglo-Saxon and Chinese studies on gentrification-induced displacement, they both emphasized the direct physical and indirect mental displacement due to the gentrification process. In Anglo-Saxon studies, the displacement is mainly resulting from individual-driven gentrification, but increasingly from state-led gentrification. Indirect displacement also puts mental stresses on the original residents of the neighbourhoods, but most of the time, they are not violently forced on being evicted, and it could also take a long-ime span to implement. In China, displacement happens more rapidly and on a large scale led by the state. Displacement could lead to two extremes. Some of the displaced residents are extremely satisfied with the compensations from the displacement. On the other hand, displacement sometimes associates with violent conflicts because of the dependency of local government's revenue source from selling land rights, the unbalance state-citizenship relationship, and the lack of the rule of law. Thus, the study of gentrification-induced displacement in China involves careful examinations of the local concepts specific to China.

\section{Future of gentrification research in China}

Gentrification is a relatively new field of research in Chinese academia since the early 2000s. Although gentrification studies have gained a lot of popularity in China, and the scholars recognized the local and national differences in China and have worked out to establish its own theories, research on gentrification in China has at least three weaknesses that require further study. First, in terms of methodology, only a small number of Chinese gentrification studies employ statistical analyses. In these studies, the statistical analyses mainly aim to present the data rather than find correlations (He, 2009; Hu, Song, Li \& Lu, 2019; Huang \& Yang, 2017; Wu \& Wang, 2017; Yang \& Zhou, 2018). The lack of statistical analysis may be due to the limited access to data. As a result, the most common methodology to examine the reasons and the impacts of gentrification were based on conceptual research (Arkaraprasertkul, 2018; Chan et al., 2016; He, 2012, 2015; Liu, Geertman, Van Oort \& Lin, 2018; Qian, He \& Liu, 2013; Wang, 2011). Many of the studies focused on describing gentrification with added Chinese 
characteristics without empirical evidence to support the arguments (He, 2007, 2019; He \& Wu, 2005, 2009; Liang \& Bao, 2015; Shin, 2016; Song et al., 2017; Wu, 2016). For example, the rent jump theory by Song et al. (2017) has a broad concept that local government sells land use rights to developers at "best use" value but lacks data or empirical evidence to support such an argument. Also, the studies on the impacts of gentrification lack or only have limited spatial analyses to demonstrate the results (He, 2012; Song \& Wu, 2010; Song \& Zhu, 2011; Wang \& Lau, 2009; Wu, Edensor, \& Cheng, 2018; Wu et al., 2016). To the extent possible, future research on gentrification in China should integrate more statistical and spatial analyses.

Second, the study of the impacts on the rental tenants due to the gentrification process is also missing in the study in China. Most of the studies focused on the property owners and the way through which they are impacted by gentrification in the form of direct displacement $(\mathrm{He} \& \mathrm{Wu}$, 2009; Huang \& Yang, 2017; Shin, 2016; Wang \& Lau, 2009; Yang \& Ley, 2018; Zhang, Hu, Skitmore \& Leung, 2014). However, rental tenants experience a more significant impact compared to property owners. Anglo-Saxon studies such as Davidson and Lees (2005) and Davidson (2008) concern about the indirect displacement and study the insecurities experienced by the private renters caused by gentrification. Gentrification studies in China have not considered this important group of people much yet.

Finally, gentrification studies in China have been using case studies extensively. However, the cases are mainly focused on studying the $1^{\text {st }}$ tier cities - Beijing, Shanghai, Shenzhen, and Guangzhou in China (Arkaraprasertkul, 2018; González Martínez, 2016; He, 2007, 2009, 2012, 2015; He \& Wu, 2005; Liu et al., 2018; Wang \& Lau, 2009; Wang, 2011). A small number of studies examine three of the $2^{\text {nd }}$ tier cities (Chengdu, Tianjin, Nanjing) in China (Huang \& Yang, 2017; Song et al., 2017; Song \& Wu, 2010; Wang \& Aoki, 2019; Wu et al., 2018; Yang \& Ley, 2018). The reason behind this spatial pattern of gentrification studies could be that the researchers are mainly located in the $1^{\text {st }}$ and $2^{\text {nd }}$ tiers cities, where most of the recognized universities and academic resources are concentrated. Although the $1^{\text {st }}$ and $2^{\text {nd }}$ tier cities are often having the most financial and political resources and among the first to be impacted by the central government's urban redevelopment policies, the urban renewal and gentrification of the $3^{\text {rd }}$ and $4^{\text {th }}$ tiers cities should also be examined by the researchers. Since 2008, Large scale shantytown redevelopment in the $3^{\text {rd }}$ and $4^{\text {th }}$ tiers cities have become an important area of focus by the central government. The state media People's Daily reported that between 2008 and 2018, the local governments have transformed numerous shantytowns into 38.96 million apartment units, and have helped 100 million people out of shantytowns (Zhao, 
2018). Many newly developed apartment buildings for previous shantytown residents are located at different sites, and the old sites were demolished and redeveloped by real estate developers for sales (Yuan et al., 2019; Zhou, 2017). Future research ought to be carried out to study the relationship between shantytown redevelopment and gentrification. The significant number of displacements and conflicts involved at shantytown/VIC redevelopment are also worth examination.

\section{Conclusions}

Chinese gentrification studies have recognized the local and national differences that are specific in China, particularly about the unique historical socialist background and some of the socialist legacies that are still influencing China today. The current stage of gentrification studies in China has moved toward producing theories in Chinese characteristics and completing case studies based on these newly produced theories. For example, the rent jump theory studied in Song et al. (2017) is an adoption of the classical Anglo-Saxon rent gap theory with a Chinese character, which captures the gentrification process in which the local government is heavily involved and from which it profits. The self-gentrification theory in Chan et al. (2016) recognizes that the longterm local residents could proactively lead gentrification and profit from the process compared to the traditional Anglo-Saxon theory, which proves that the gentrified may not always lose in the process. Although similar self-gentrification practices are emerging in Western societies driven by urban revitalization strategist Mahira Carter, no systematic study of this concept exists. The study by Chan et al. (2016) on self-gentrification would contribute to enhancing the theory of gentrification in a significant way.

Gentrification is no longer only a Global North concept. It is a phenomenon that exists globally. No matter where gentrification takes place, it can be studied in a universally applied paradigm. In terms of concepts, gentrification is about the change of the neighbourhood and its associated social-economic classes. In terms of theories, gentrification can be explained based on either production-based, rent-gap theory or consumption-based, change of societal need theory. In terms of the consequences, both direct physical and indirect mental displacement could be observed. Although the broad paradigm is the same, the challenges of studying gentrification in any country are to transfer and adapt the broad paradigm to capture the complexities of local conditions and to produce concepts and theories of their own. 
Acknowledgements: This research is financially supported by the International Council of Canadian, Chinese, African Sustainable Urban Development (ICCCASU), a think tank jointlyestablished by UN-Habitat and the University of Ottawa. The research conception is based on an assignment for a graduate course titled "Place \& Social Transformations" taught by Luisa Veronis in the Doctorate in Philosophy Geography program, at the University of Ottawa. We thank Luisa Veronis for her feedback on the assignment.

Authorship statement: The authors declare no conflict of interest. The participation of the authors in the article is as follow: research framework was designed by Haotian Guan and Huhua Cao. Material preparation, article collection and bibliometric analysis were performed by Haotian Guan. The first draft of the manuscript was written by Haotian Guan. Huhua Cao commented and edited on previous versions of the manuscript. All authors read and approved the final manuscript. 


\section{References}

Aalbers, M. B. (2019). Introduction To The Forum: From Third To Fifth-Wave Gentrification. Tijdschrift voor economische en sociale geografie, 110(1), 111. https://doi.org/10.1111/tesg. 12332

Aalbers, M. B., \& Christophers, B. (2014). Centring Housing in Political Economy. Housing, Theory and Society, 31(4), 373-394. https://doi.org/10.1080/14036096.2014.947082

Arkaraprasertkul, N. (2018). Gentrifying heritage: how historic preservation drives gentrification in urban Shanghai. International Journal of Heritage Studies, 25(9), 882896. https://doi.org/10.1080/13527258.2018.1460732

Atkinson, R. (2008). Commentary: Gentrification, Segregation and the Vocabulary of Affluent Residential Choice. Urban Studies, 45(12), 26262636. https://doi.org/10.1177/0042098008097110

Banzhaf, H. S., \& Walsh, R. P. (2008). Do People Vote with Their Feet? An Empirical Test of Tiebout. American Economic Review, 98(3), 843-863. https://doi.org/10.1257/aer.98.3.843

Betancur, J. J. (2014). Gentrification in Latin America: Overview and Critical Analysis. Urban Studies Research, (2014), 1-14. https://doi.org/10.1155/2014/986961

Cameron, S. (2003). Gentrification, Housing Redifferentiation and Urban Regeneration: 'Going for Growth' in Newcastle upon Tyne. Urban Studies, 40(12), 2367 2382. https://doi.org/10.1080/0042098032000136110

Chai, Y. (2014). From socialistdanweito newdanwei: a daily-life-based framework for sustainable development in urban China. Asian Geographer, 31(2), 183190. https://doi.org/10.1080/10225706.2014.942948

Chan, J. H., lankova, K., Zhang, Y., McDonald, T., \& Qi, X. (2016). The role of self-gentrification in sustainable tourism: Indigenous entrepreneurship at Honghe Hani Rice Terraces World Heritage Site, China. Journal of Sustainable Tourism, 24(8-9), 12621279. https://doi.org/10.1080/09669582.2016.1189923

Clark, E. (1988). The rent gap and transformation of the built enviroment: case studies in Malmo 1860-1985. Geografiska Annaler: Series B, Human Geography, 70(2), 241 254. https://doi.org/10.1080/04353684.1988.11879569 
Congressional - Executive Commission on China. (2018). Campaign of Forced Evictions in Beijing Contravenes International Human Rights Standards. Retrieved from https://www.cecc.gov/publications/commission-analysis/campaign-of-forced-evictions-inbeijing-contravenes-international

Davidson, M. (2008). Spoiled Mixture: Where Does State-led 'Positive' Gentrification End? Urban Studies, 45(12), 2385-2405. https://doi.org/10.1177/0042098008097105

Davidson, M., \& Lees, L. (2005). New-Build 'Gentrification' and London's Riverside Renaissance. 37(7), 1165-1190. https://doi.org/10.1068/a3739

E-House China. (2018). Ziroom: Winning in China's Housing Rental Services Market. Retrieved from https://knowledge.wharton.upenn.edu/article/ziroom-winning-chinas-housing-rentalservices-market/

Elmer, K. (2018, November 18). A year after deadly Daxing fire, no let-up in campaign to marginalise migrant workers. Retrieved from

https://www.scmp.com/news/china/society/article/2173745/year-after-deadly-daxing-fire-nolet-campaign-marginalise-migrant

Friedmann, J. (2007). Reflections on Place and Place-making in the Cities of China. International Journal of Urban and Regional Research, 31(2), 257-279. https://doi.org/10.1111/j.1468$\underline{2427.2007 .00726 . x}$

Gaudreau, M. (2013). Situating Adaptive Enviromental Governance: Non-governmental Actors in the Protection of Nanjing's Qinhuai River. (Master's of Globalization and International Development, University of Ottawa, Canada). Retrieved from Retrieved from https://ruor.uottawa.ca/handle/10393/24285

Ghertner, D. A. (2015). Why gentrification theory fails in 'much of the world'. City, 19(4), 552563. https://doi.org/10.1080/13604813.2015.1051745

Glass, R. L. (1964). London: aspects of change (Vol. 3). MacGibbon \& Kee.

González Martínez, P. (2016). Authenticity as a challenge in the transformation of Beijing's urban heritage: The commercial gentrification of the Guozijian historic area. Cities, 59, 4856. https://doi.org/10.1016/j.cities.2016.05.026

Hamnett, C. (1991). The Blind Men and the Elephant: The Explanation of Gentrification. Transactions of the Institute of British Geographers, 16(2), 173. https://doi.org/10.2307/622612 
Harvey, D. (2003). The New Imperialism. Oxford: Oxford University Press.

He, S. (2007). State-Sponsored Gentrification Under Market Transition: the case of Shanghai. Urban Affairs Review, 43(2). https://doi.org/10.1177/1078087407305175

He, S. (2009). New-build gentrification in central Shanghai: demographic changes and socioeconomic implications. Population, Space and Place, n/an/a. https://doi.org/10.1002/psp.548

He, S. (2012). Two waves of gentrification and emerging rights issues in Guangzhou, China.

Environment and Planning A: Economy and Space, 44(12), 28172833. https://doi.org/10.1068/a44254

He, S. (2015). Consuming urban living in 'villages in the city': Studentification in Guangzhou, China. Urban Studies, 52(15), 2849-2873. https://doi.org/10.1177/0042098014543703

He, S. (2019). Three Waves of State-led Gentrification in China. Tijdschrift voor economische en sociale geografie, 110(1), 26-34. https://doi.org/10.1111/tesg. 12334

He, S., \& Wu, F. (2005). Property-Led Redevelopment in Post-Reform China: A Case Study of Xintiandi Redevelopment Project in Shanghai. Journal of Urban Affairs, 27(1), 123. https://doi.org/10.1111/j.0735-2166.2005.00222.x

He, S., \& Wu, F. (2009). China's Emerging Neoliberal Urbanism: Perspectives from Urban Redevelopment. Antipode, 41(2), 282-304. https://doi.org/10.1111/i.14678330.2009.00673.x

He, S., Zhang, M., \& Wei, Z. (2020). The state project of crisis management: China's Shantyłown Redevelopment Schemes under state-led financialization. Environment and Planning A: Economy and Space, 52(3), 632-653.

Hu, S., Song, W., Li, C., \& Lu, J. (2019). School-gentrifying community in the making in China: Its formation mechanisms and socio-spatial consequences. Habitat International, 93, 102045. https://doi.org/10.1016/i.habitatint.2019.102045

Huang, X., \& Yang, Y. (2017). Urban redevelopment, gentrification and gentrifiers in post-reform inland China: A case study of Chengdu, China. Chinese Geographical Science, 27(1), 151164. https://doi.org/10.1007/s11769-017-0852-3 
Jackson, L. K. (2017). The Complications of Colonialism for Gentrification Theory and Marxist Geography. Journal of Law and Social Policy, 27, 43-71. Retrieved from https://digitalcommons.osgoode.yorku.ca/jlsp/vol27/iss1/4/

Janoschka, M., Sequera, J., \& Salinas, L. (2014). Gentrification in Spain and Latin America - a Critical Dialogue. International Journal of Urban and Regional Research, 38(4), 12341265. https://doi.org/10.1111/1468-2427.12030

Kaiman, J. (2017, November 29). In Beijing, a mass eviction leads to a rare public display of rage. Retrieved from https://www.latimes.com/world/asia/la-fg-china-evictions-20171130story.html

Lees, L. (2016). Planetary gentrification. Cambridge: Polity Press.

Ley, D. (1986). Alternative Explanations for Inner-City Gentrification: A Canadian Assessment. Annals of the Association of American Geographers, 76(4), 521535. https://doi.org/10.1111/j.1467-8306.1986.tb00134.x

Ley, D. (1994). Gentrification and the politics of the new middle class. Environment and Planning D: Society and Space, 12(1), 53-74. https://doi.org/10.1068/d120053

Ley, D. (2003). Artists, Aestheticisation and the Field of Gentrification. Urban Studies, 40(12), 2527-2544. https://doi.org/10.1080/0042098032000136192

Ley, D., \& Teo, S. Y. (2014). Gentrification in Hong Kong? Epistemology vs. Ontology. International Journal of Urban and Regional Research, 38(4), 12861303. https://doi.org/10.1111/1468-2427.12109

Li, G. (2018). Spatial-Temporal Patterns of the Distribution of the Ethnic Minorities in China's Urbanization (Master of Arts in Geography, University of Ottawa, Ottawa, Canada). Retrieved from https://ruor.uottawa.ca/handle/10393/37077

Liang, Z.-X., \& Bao, J.-G. (2015). Tourism gentrification in Shenzhen, China: causes and sociospatial consequences. Tourism Geographies, 17(3), 461 481. https://doi.org/10.1080/14616688.2014.1000954

Lin, G. C. S. (2012). Chinese metropolises in transformation: state power reshuffling, land commodification and uneven urban development. Paper presented at the International Conference on Spatial and Social Transformation in Urban China, Hong Kong. 
Liu, L., \& Xu, Z. (2018). Collaborative governance: A potential approach to preventing violent demolition in China. Cities, 79, 26-36. https://doi.org/10.1016/j.cities.2018.02.019

Liu, R., \& Wong, T.-C. (2018). Urban village redevelopment in Beijing: The state-dominated formalization of informal housing. Cities, $72, \quad$ 160172. https://doi.org/10.1016/j.cities.2017.08.008

Liu, Y., Geertman, S., Van Oort, F., \& Lin, Y. (2018). Making the 'Invisible' Visible: Redevelopment-induced Displacement of Migrants in Shenzhen, China. International Journal of Urban and Regional Research, 42(3), 483-499. https://doi.org/10.1111/1468-2427.12646

Liu, Z., \& Cao, H. (2016). Spatio-temporal urban social landscape transformation in pre-newurbanization era of Tianjin, China. Environment and Planning B: Urban Analytics and City Science, 44(3), 398-424. https://doi.org/10.1177/0265813516637606

López-Morales, E. (2015). Gentrification in the global South. City, 19(4), 564573. https://doi.org/10.1080/13604813.2015.1051746

Maloutas, T. (2012). Contextual Diversity in Gentrification Research. Critical Sociology, 38(1), $33-$ 48. https://doi.org/10.1177/0896920510380950

Man, J. Y., Zheng, S., \& Ren, R. (2011). Housing Policy and Housing Markets:

Trends, Patterns, and Affordability. In J. Y. Man (Ed.), China's Housing Reform and Outcomes. Cambridge, Mass: Lincoln Institute of Land Policy.

Mermet, A.-C. (2017). Global retail capital and the city: towards an intensification of $\begin{array}{llll}\text { gentrification. Urban } \quad \text { Geography, } & \text { 3158), }\end{array}$ 1181. https://doi.org/10.1080/02723638.2016.1200328

Palen, J. J., \& London, B. (1984). Gentrification, Displacement, and Neighborhood Revitalization: State University of New York Press.

Phillips, T. (2017, December 8). The gentrification of Beijing: razing of migrant villages spells end of China dream. Retrieved from https://www.theguardian.com/world/2017/dec/08/beijing-gentrification-china-migrantvillages-destroyed

Qian, J., He, S., \& Liu, L. (2013). Aestheticisation, rent-seeking, and rural gentrification amidst China's rapid urbanisation: The case of Xiaozhou village, Guangzhou. ournal of Rural Studies, 32, 331-345. https://doi.org/10.1016/j.jrurstud.2013.08.002 
Ren, J. (2015). Gentrification in China? In L. Lees, H. B. Shin \& E. L. Morales (Eds.), Global Gentrifications: Uneven Development and Displacement (pp. 329-347). Bristol: Policy Press.

Shaw, K. (2008). Gentrification: What It Is, Why It Is, and What Can Be Done about It. Geography Compass, 2(5), 1697-1728. https://doi.org/10.1111/j.1749-8198.2008.00156.x

Shi, S. (2017, November 29). 图解：北京最新清理整治行动，影响范围有多广? [Diagram Illustration: The Most Recent Beijing Clean Up Movement, What are the impacts?]. Retrieved from https://www.ftchinese.com/story/001075262?archive

Shin, H. B. (2013). The Right to the City and Critical Reflections on China's Property Rights Activism. Antipode. https://doi.org/10.1111/anti. 12010

Shin, H. B. (2016). Economic transition and speculative urbanisation in China: Gentrification versus $\quad$ dispossession. Urban 57udies, 489. hitps://doi.org/10.1177/0042098015597111

Sieg, H., Smith, V. K., Banzhaf, H. S., \& Walsh, R. (2004). Estimating the General Equilibrium Benefits of Large Changes in Spatially Delineated Public Goods. International Economic Review, 45(4), 1047-1077. Retrieved from http://www.jstor.org/stable/3663619

Smith, D. P. (2002a). Extending the temporal and spatial limits of gentrification: a research agenda for population geographers. International Journal of Population Geography, 8(6), 385394. hitps://doi.org/10.1002/ijpg.267

Smith, D. P. (2004). 'Studentification ication': the gentrification factory? In R. Atkinson \& G. Bridge (Eds.), Gentrification in a Global Context (pp. 72-89) London: Routledge.

Smith, N. (1979). Toward a Theory of Gentrification A Back to the City Movement by Capital, not People. Journal of the American Planning Association, 45(4), 538548. https://doi.org/10.1080/01944367908977002

Smith, N. (1982). Gentrification and Uneven Development. Economic Geography, 58(2), 139. hitps://doi.org/10.2307/143793

Smith, N. (1996). The New Urban Frontier: Gentrification and the Revanchist City. Florence: Routledge.

Smith, N. (2002b). New Globalism, New Urbanism: Gentrification as Global Urban Strategy. Antipode, 34(3), 427-450. hittps://doi.org/10.1111/1467-8330.00249 
Solinger, D. J. (1999). Contesting Citizenship in Urban China: Peasant Migrants, the State, and the Logic of the Market. Berkeley: University of California Press.

Song, W., Liu, C., Wang, Y., \& Yuan, Y. (2017). Rent gap and gentrification in the inner city of

Nanjing. ACTA Geographica Sinica, 72(12),

2130. https://doi.org/10.11821/dlxb201712001

Song, W., \& Wu, Q. (2010). Gentrification and residential differentiation in Nanjing, China. Chinese Geographical Science, 20(6), 568-576. https://doi.org/10.1007/s11769-010-0432-2

Song, W., \& Zhu, X. (2011). Gentrification in Urban China under Market Transformation. $\begin{array}{llll}\text { International Journal Urban } & \text { Sciences, }\end{array}$ 163. https://doi.org/10.1080/12265934.2010.9693673

Visser, G., \& Kotze, N. (2008). The State and New-build Gentrification in Central Cape Town, South Africa. Urban Studies, 45(12), 25652593. https://doi.org/10.1177/0042098008097104

Wang, J., \& Lau, S. S. Y. (2009). Gentrification and Shanghai's new middle-class: Another reflection on the cultural consumption thesis. 26(2), 5766. https://doi.org/10.1016/j.cities.2009.01.004

Wang, S. W.-H. (2011). Commercial Gentrification and Entrepreneurial Governance in Shanghai: A Case Study of Taikang Road Creative Cluster. Urban Policy and Research, 29(4), 363380. https://doi.org/10.1080/08111146.2011.598226

Wang, X., \& Aoki, N. (2019). Paradox between neoliberal urban redevelopment, heritage conservation, and community needs: Case study of a historic neighbourhood in Tianjin, China. Cities, 85, 156-169. https://doi.org/10.1016/j.cities.2018.09.004

Wang, Y. P., \& Murie, A. (1996). The Process of Commercialisation of Urban Housing in China. Urban Studies, 33(6), 971-989. Retrieved from http://www.jstor.org/stable/43100335

Weiler, L. (2015). Navigating Ethnic Identity in Neighbourhoods of Difference: Resident Perceptions of Urban Space in Ürümqi, China (MA in Globalization and International Development, University of Ottawa, Canada). Retrieved from https://ruor.uottawa.ca/handle/10393/32498

Wu, F. (2016). State Dominance in Urban Redevelopment: Beyond Gentrification in Urban China. Urban Affairs Review, 52(5), 631-658. https://doi.org/10.1177/1078087415612930 
Wu, Q., Edensor, T., \& Cheng, J. (2018). Beyond Space: Spatial (Re)Production and MiddleClass Remaking Driven by Jiaoyufication in Nanjing City, China. International Journal of Urban and Regional Research, 42(1), 1-19. https://doi.org/10.1111/1468-2427.12568

Wu, Q., Zhang, X., \& Waley, P. (2016). Jiaoyufication: When gentrification goes to school in the Chinese inner Uity. Urban Studies, 53(16), 3526. https://doi.org/10.1177/0042098015613234

Wu, W., \& Wang, J. (2017). Gentrification effects of China's urban village renewals. Urban Studies, 54(1), 214-229. https://doi.org/10.1177/0042098016631905

Xinhua News Agency (2018, August 20). 谁在操纵北京房租上涨? 房产中介高价抢收房源 [What leads to the increase of rent in Beijing? Real Estate Agents Pay High Price for Getting the Units]. In Xinhua Net. Retrieved from http://www.xinhuanet.com/politics/2018$\underline{08 / 20 / C \_1123294145 . h t m}$

Xue, D. (1999). Research on gentrification in western countries and its implications for urban socio-spatial research in China. Planner, 15(3), 109-112.

Yang, Q., \& Ley, D. (2018). Residential relocation and the remaking of socialist workers through state-facilitated urban redevelopment in Chengdu, China. Urban Studies, 004209801879072. https://doi.org/10.1177/0042098018790724

Yang, Q., \& Zhou, M. (2018). Interpreting gentrification in Chengdu in the post-socialist transition of China: A sociocultural perspective. Geoforum, 93, 120132. https://doi.org/10.1016/j.geoforum.2018.05.014

Yuan, S., Niu, M., Shi, W., Hong, T., Yanan, Q., \& Teng, J. X. (2019, September 16). In Depth: The Violence Behind 'Shantytown' Redevelopment. In Caixin Global. Retrieved from https://www.caixinglobal.com/2019-09-16/in-depth-the-violence-behind-shantytownredevelopment-101462547.html

Zhang, X., Hu, J., Skitmore, M., \& Leung, B. Y. P. (2014). Inner-City Urban Redevelopment in China Metropolises and the Emergence of Gentrification: Case of Yuexiu, Guangzhou. Journal of Urban Planning and Development, 140(4), 05014004. https://doi.org/10.1061/(asce)up.19435444.0000169

Zhang, Y. (2018). Domicide, social suffering and symbolic violence in contemporary Shanghai, China. Urban Geography, 39(2), 190-213. https://doi.org/10.1080/02723638.2017.1298978 
Zhang, Z., \& He, S. (2018). Chapter 9: Gentrification-induced displacement. In L. Lees \& M. Phillips (Eds.), Handbook of Gentrification Studies (pp. 134-152). Cheltenham: Edward Elgar Publishing.

Zhao, Z. (2018, August 27). 棚改 10 年来全国累计开工 3896 万套 圆一亿人安居梦 [Shandytown Redevelopment in the Past 10 Years Includes 38.96 Units Help 100 Million People to Reach thier Dreams]. In People.cn Retrieved from http://politics.people.com.cn/n1/2018/0827/c1001-30252340.html

Zhou, W. (2017, February 22). In Depth: The Violence Behind 'Shantytown' Redevelopment. In Caixin Global. Retrieved from https://www.caixinglobal.com/2019-09-16/in-depth-the-violencebehind-shantytown-redevelopment-101462547.html

Zukin, S., Trujillo, V., Frase, P., Jackson, D., Recuber, T., \& Walker, A. (2009). New Retail Capital and Neighborhood Change: Boutiques and Gentrification in New York City. City \& Community, 8(1), 47-64. hittps://doi.org/10.1111/j.1540-6040.2009.01269.x 